\title{
Bad Smells and Broken DNA: A Tale of Sulfur-Nucleic Acid Cooperation
}

\author{
Rodney E. Shackelford ${ }^{1, *(\mathbb{D})}$, Yan Li $^{1}{ }^{1}$, Ghali E. Ghali ${ }^{2}$ and Christopher G. Kevil ${ }^{1}$ \\ 1 Department of Pathology and Translational Pathobiology, Louisiana State University Health Sciences Center, \\ Shreveport, LA 71130, USA; yan.li@lsuhs.edu (Y.L.); chris.kevil@lsuhs.edu (C.G.K.) \\ 2 Head \& Neck Oncologic/Microvascular Reconstructive Surgery Department of Oral \& Maxillofacial/Head \& \\ Neck Surgery, Louisiana State University Health Sciences Center, Shreveport, LA 71130, USA; \\ gghali@lsuhs.edu \\ * Correspondence: Rodney.Shackelford@lsuhs.edu or RdnyShac@aol.com; Tel.: +1-318-525-6479
}

check for updates

Citation: Shackelford, R.E.; Li, Y.; Ghali, G.E.; Kevil, C.G. Bad Smells and Broken DNA: A Tale of Sulfur-Nucleic Acid Cooperation. Antioxidants 2021, 10, 1820. https:// doi.org/10.3390/antiox10111820

Academic Editor: Mikko

O. Laukkanen

Received: 19 October 2021

Accepted: 13 November 2021

Published: 17 November 2021

Publisher's Note: MDPI stays neutral with regard to jurisdictional claims in published maps and institutional affiliations.

Copyright: (c) 2021 by the authors. Licensee MDPI, Basel, Switzerland. This article is an open access article distributed under the terms and conditions of the Creative Commons Attribution (CC BY) license (https:// creativecommons.org/licenses/by/ $4.0 /)$.

\begin{abstract}
Hydrogen sulfide $\left(\mathrm{H}_{2} \mathrm{~S}\right)$ is a gasotransmitter that exerts numerous physiologic and pathophysiologic effects. Recently, a role for $\mathrm{H}_{2} \mathrm{~S}$ in DNA repair has been identified, where $\mathrm{H}_{2} \mathrm{~S}$ modulates cell cycle checkpoint responses, the DNA damage response (DDR), and mitochondrial and nuclear genomic stability. In addition, several DNA repair proteins modulate cellular $\mathrm{H}_{2} \mathrm{~S}$ concentrations and cellular sulfur metabolism and, in turn, are regulated by cellular $\mathrm{H}_{2} \mathrm{~S}$ concentrations. Many DDR proteins are now pharmacologically inhibited in targeted cancer therapies. $\mathrm{As}_{2} \mathrm{H}_{2} \mathrm{~S}$ and the enzymes that synthesize it are increased in many human malignancies, it is likely that $\mathrm{H}_{2} \mathrm{~S}$ synthesis inhibition by these therapies is an underappreciated aspect of these cancer treatments. Moreover, both $\mathrm{H}_{2} \mathrm{~S}$ and DDR protein activities in cancer and cardiovascular diseases are becoming increasingly apparent, implicating a DDR- $\mathrm{H}_{2} \mathrm{~S}$ signaling axis in these pathophysiologic processes. Taken together, $\mathrm{H}_{2} \mathrm{~S}$ and DNA repair likely play a central and presently poorly understood role in both normal cellular function and a wide array of human pathophysiologic processes. Here, we review the role of $\mathrm{H}_{2} \mathrm{~S}$ in DNA repair.
\end{abstract}

Keywords: hydrogen sulfide; DNA repair; cystathionine $\beta$-synthase; cystathionine $\gamma$-lyase; 3 mercaptopyruvate sulfurtransferase; ATR; MEK1; autophagy

\section{Introduction}

The maintenance of genomic stability is essential for life, and cells have evolved complex and intricate molecular machinery to ensure DNA stability and accurate DNA replication [1-4]. Eukaryotic cells carry two separate genomes with different evolutionary origins [4,5]. The nuclear genome is diploid, linear, and in humans contains roughly 3.3 billion base pairs encoding over 20,000 genes [4,5]. Conversely, the mitochondrial genome is circular, contains 37 genes in 16,569 base pairs, and occurs in multiple copies at 100-1000/cell [4,5]. The two genomes extensively interact, with the nuclear genome encoding roughly 1500 mitochondrial proteins, including those involved in mitochondrial DNA repair, while mitochondrial genomic damage can initiate apoptotic cell death via cytochrome c release and can also activate the innate immune response [4-7]. Hydrogen sulfide $\left(\mathrm{H}_{2} \mathrm{~S}\right)$ is a gasotransmitter that, along with nitric oxide and carbon monoxide, functions in a vast number of different physiologic and pathophysiologic processes [8,9]. Specifically, $\mathrm{H}_{2} \mathrm{~S}$ has many physiologic regulatory roles, including in the renal, cardiovascular, central nervous, and digestive systems, and is also dysregulated in many different pathologic processes including cancer, cardiovascular diseases, and neurodegeneration [10-17]. Recently, $\mathrm{H}_{2} \mathrm{~S}$ has been found to regulate mitochondrial and nuclear DNA stability and repair [11-13]. Here, we review this new area of inquiry and discuss its possible implications for cancer chemotherapy and cardiovascular diseases. 


\section{2. $\mathrm{H}_{2} \mathrm{~S}$ Chemistry, Synthesis, and Catabolism}

\section{1. $\mathrm{H}_{2} \mathrm{~S}$ Chemistry}

$\mathrm{H}_{2} \mathrm{~S}$ has been known for over 300 years as an environmental toxin with high $\mathrm{H}_{2} \mathrm{~S}$ concentrations causing damage in multiple organs, difficulty with breathing, shock, and convulsions, which may lead to death [18]. $\mathrm{H}_{2} \mathrm{~S}$ toxicity occurs following cytochrome $\mathrm{c}$ oxidase, carbonic anhydrase, $\mathrm{Na}^{+} / \mathrm{K}^{+}$ATPase, monoamine oxidase, and possibly ATR kinase inhibition [12,18-21]. $\mathrm{H}_{2} \mathrm{~S}$ is a colorless, weak diprotic acid with a characteristic rotten egg smell, with first and second pKa values of 6.76 and 19 at $37{ }^{\circ} \mathrm{C}$ [18]. At pH 7.4, $\mathrm{H}_{2} \mathrm{~S}$ is $\sim 70-80 \% \mathrm{HS}^{-}, \sim 20 \% \mathrm{H}_{2} \mathrm{~S}$, with low very concentrations of $\mathrm{S}_{2}{ }^{-}$[19]. $\mathrm{H}_{2} \mathrm{~S}$ readily diffuses across biological membranes [22]. $\mathrm{HS}^{-}$has high nucleophilicity and chemical reactivity, but it is not membrane permeable, although it may cross membranes due to its rapid interconversion with $\mathrm{H}_{2} \mathrm{~S}$ or through specific transporters [9,22-24]. The minus two sulfur oxidation state in $\mathrm{H}_{2} \mathrm{~S}$ renders it an obligatory reductant, and $\mathrm{H}_{2} \mathrm{~S}$ exerts numerous antioxidant effects [9,24-26]. However, cellular $\mathrm{H}_{2} \mathrm{~S}$ concentrations are low at $10-30 \mathrm{nM}$, and $\mathrm{H}_{2} \mathrm{~S}$ reacts too slowly with oxidants, such as $\mathrm{H}_{2} \mathrm{O}_{2}$ and hypochlorite, to exert significant antioxidant effects $[14,19,27-29]$. Thus, its antioxidants effects are likely mediated through events such as the $\mathrm{H}_{2} \mathrm{~S}$-mediated induction of glutathione synthesis and cystine uptake, the inhibition of mitochondrial free radical production, and $\mathrm{Nrf} 2$ induction $[9,25,27] . \mathrm{H}_{2} \mathrm{~S}$ exists in thermodynamic equilibrium with other sulfur species including persulfides, polysulfides, and reactive sulfur species. The roles of these compounds in human health and disease are presently poorly understood and are an area of intense investigation [14]. The cell and tissue $\mathrm{H}_{2} \mathrm{~S}$ half-lives are short, being only a few minutes $[9,19]$.

\section{2. $\mathrm{H}_{2} \mathrm{~S}$ Synthesis}

Biological $\mathrm{H}_{2} \mathrm{~S}$ synthesis was first identified in bacteria in 1895, and it was not until 1996 that endogenous $\mathrm{H}_{2} \mathrm{~S}$ as a biological modulator in humans was identified [10,30]. In mammals $\mathrm{H}_{2} \mathrm{~S}$ is primarily synthesized by three systems which contribute unequally to the sulfur pool: (1) enzymatic synthesis, (2) non-enzymatic synthesis, and (3) microbiome production. Enzymatic $\mathrm{H}_{2} \mathrm{~S}$ synthesis occurs through three enzymes: cystathionine $\gamma$-lyase (CSE), cystathionine $\beta$-synthase (CBS), and 3-mercaptopyruvate sulfurtransferase (3-MST, [9]). These enzymes show tissue and organ-specific distributions patterns $[8,10,31,32]$. CSE is predominantly found within the vasculature, while CBS occurs in the liver, brain, and nervous system, and 3-MST occurs mainly in the vasculature and the brain [10,31,32]. CSE and CBS are predominantly cytosolic pyridoxal-5'-phosphatedependent hemeproteins, while 3-MST is mainly mitochondrial and synthesizes roughly $90 \%$ of brain $\mathrm{H}_{2} \mathrm{~S}$ [10,31-33].

The enzymatic synthesis of $\mathrm{H}_{2} \mathrm{~S}$ in mammals requires methionine and cysteine, with methionine being derived solely from the diet, as it cannot be synthesized in mammalian tissues [19,34]. These amino acids are converted into homocysteine by the transsulfuration pathway $[19,34]$. CBS synthesizes $\mathrm{H}_{2} \mathrm{~S}$ by catalyzing homocysteine and L-cysteine to form cystathionine and $\mathrm{H}_{2} \mathrm{~S}[19,35]$. CBS generates $\mathrm{H}_{2} \mathrm{~S}$ through a $\beta$-replacement reaction also producing serine. In the presence of homocysteine $\mathrm{H}_{2} \mathrm{~S}$ synthesis increases 23 -fold compared to the reaction with L-cysteine alone $[19,36]$. CBS also catalyzes the condensation of L-serine and homocysteine, forming cystathionine and $\mathrm{H}_{2} \mathrm{O}$, a significant step in L-cysteine biosynthesis [37]. CSE catalyzes homocysteine, generating $\mathrm{H}_{2} \mathrm{~S}, \alpha$-ketobutyrate, and $\mathrm{NH}_{3}[9,19,38]$. Interestingly, at physiologic L-cysteine and homocysteine concentrations, roughly $70 \%$ of the $\mathrm{H}_{2} \mathrm{~S}$ synthesized for the CSE-mediated $\alpha, \beta$-elimination of L-cysteine, while the $\alpha, \gamma$-elimination of homocysteine contributes approximately $29 \%$ of the total $\mathrm{H}_{2} \mathrm{~S}$ content; however, roughly $90 \%$ of the $\mathrm{H}_{2} \mathrm{~S}$ is derived from the $\alpha, \gamma$-elimination of homocysteine when its levels are increased to those seen in hyperhomocysteinemia [38]. 3-MST $\mathrm{H}_{2} \mathrm{~S}$ synthesis requires cysteine aminotransferase to convert L-cysteine into 3mercaptopyruvate, which is then catalyzed by 3-MST into $\mathrm{H}_{2} \mathrm{~S}$ and pyruvate [39]. Dcysteine can be converted to 3-mercaptopyruvate by the peroxisome-located D-amino acid oxidase, which, once imported into the mitochondrion, is converted into $\mathrm{H}_{2} \mathrm{~S}$ by 3-MST. As 
D-amino acid oxidase expression is limited to the brain and kidneys, this $\mathrm{H}_{2} \mathrm{~S}$ synthesis pathway is likely limited to those organs [40].

Based on its chemistry, the molecular mechanisms of $\mathrm{H}_{2} \mathrm{~S}$ reactivity have been placed into three categories: (1) chemical interfacing/scavenging with reactive oxygen and nitrogen species, (2) chemical modification of protein cysteines to persulfides, and (3) binding to and/or redox reactions with metal centers [9]. Intracellular $\mathrm{H}_{2} \mathrm{~S}$ exists as free $\mathrm{H}_{2} \mathrm{~S}$, acidlabile sulfide, and bound sulfane sulfur [19]. The acid-labile sulfide faction consists of sulfur present in iron-sulfur clusters contained within iron-sulfur proteins (non-heme), which are ubiquitous and include ferredoxins, rubredoxins, aconitase, and succinate dehydrogenase [19]. The sulfane sulfur fraction consists of sulfur atoms bound only to other sulfur atoms, these include thiosulfate $\mathrm{S}_{2} \mathrm{O}_{3}{ }^{2-}$, persulfides, $\mathrm{R}-\mathrm{S}-\mathrm{SH}$, thiosulfonates $\mathrm{R}-\mathrm{S}(\mathrm{O})-\mathrm{S}-\mathrm{R}^{\prime}$, polysulfides $\mathrm{R}-\mathrm{S}_{\mathrm{n}}-\mathrm{R}$, polythionates $\mathrm{S}_{\mathrm{n}} \mathrm{O}_{6}{ }^{2-}$, and elemental sulfur $\mathrm{S}^{0}$ [19]. Free cellular $\mathrm{H}_{2} \mathrm{~S}$ represents less than $1 \%$ of the potentially available sulfide, indicating that the endogenous sulfide pool likely has significant buffering capacity [9].

\subsection{Non-Enzymatic $\mathrm{H}_{2} \mathrm{~S}$ Synthesis}

$\mathrm{H}_{2} \mathrm{~S}$ is also synthesized through non-enzymatic mechanisms and occurs by an iron and vitamin $\mathrm{B}_{6}$-mediated catalysis of $\mathrm{L}$ - or $\mathrm{D}$-cysteine producing pyruvate, $\mathrm{NH}_{3}$, and $\mathrm{H}_{2} \mathrm{~S}$ [41]. This $\mathrm{H}_{2} \mathrm{~S}$ synthesizing pathway likely plays a role in maintaining basal $\mathrm{H}_{2} \mathrm{~S}$ levels and may be an important $\mathrm{H}_{2} \mathrm{~S}$ source in iron overload and hemorrhagic disorders [41]. Lastly, the mammalian microbiome regulates systemic $\mathrm{H}_{2} \mathrm{~S}$ bioavailability and metabolism. Germ-free mice show significantly lower plasma and gastrointestinal $\mathrm{H}_{2} \mathrm{~S}$ and $50-80 \%$ lower plasma, adipose, and lung tissue bound sulfane sulfur compared to conventionally housed mice. Interestingly, CSE activity was reduced in many organs of the germ-free mice, while tissue cysteine levels were elevated [42].

\section{4. $\mathrm{H}_{2} \mathrm{~S}$ Catabolism}

High cellular $\mathrm{H}_{2} \mathrm{~S}$ concentrations can be toxic, and excess $\mathrm{H}_{2} \mathrm{~S}$ is predominately removed by the stringently regulated mitochondrial sulfur oxidation pathway [43]. $\mathrm{H}_{2} \mathrm{~S}$ catabolism is initiated by the mitochondrial matrix flavoprotein sulfide quinone oxidoreductase (SQR), which oxidizes $\mathrm{H}_{2} \mathrm{~S}$ to form an SQR-persulfide intermediate. The persulfide is then transferred to glutathione to form glutathione persulfide, which is further oxidized by the ethylmalonic encephalopathy 1 or thiosulfate sulfurtransferase proteins to form sulfite or thiosulfate, respectively [43-45]. The sulfite and thiosulfate are ultimately excreted in the urine [46]. The electrons released by SQR enter complex III of the electron transport chain and are used to generate ATP, making $\mathrm{H}_{2} \mathrm{~S}$ an inorganic compound capable driving mitochondrial ATP synthesis [47]. Outside of this review, however, polysulfides can be synthesized by all three $\mathrm{H}_{2} \mathrm{~S}$-sythesizing enzymes and increasingly have been found to play important functions in many physiologic and pathophysiologic processes $[29,48,49]$.

\section{Life's Origin and $\mathrm{H}_{2} \mathrm{~S}$}

\subsection{Life's Origin and $\mathrm{H}_{2} \mathrm{~S}$}

Biochemical, fossil, and molecular clock dating methods indicate that life first appeared 3.7 to 4.2 billion years ago in a reducing, ferruginous, and euxinic environment probably at hydrothermal vents rich in $\mathrm{NH}_{3}, \mathrm{~N}_{2}, \mathrm{CO}_{2}, \mathrm{CO}, \mathrm{CH}_{4}, \mathrm{H}_{2}, \mathrm{H}_{2} \mathrm{~S}$, and dissolved metals, especially $\mathrm{Fe}^{2+}$ and $\mathrm{Mn}^{2+}$ [50-55]. Due to the fact of its ubiquity on the early Earth and versatile chemistry, $\mathrm{H}_{2} \mathrm{~S}$ likely played an essential role in prebiotic chemistry and the emergence of life $[52,54,55]$. Support for this comes from analyses demonstrating that reactive oxygen and reactive sulfur species detoxifying mechanisms have been present since the origin of life, some four billion years ago, and have continued to the present in the biochemistry of the Archaea, Bacteria, and Eukarya [50-56]. Since genomic stability maintenance is an ancient and absolute requirement for life, and $\mathrm{H}_{2} \mathrm{~S}$ biochemistry is similarly ancient and ubiquitous, it is very likely that $\mathrm{H}_{2} \mathrm{~S}$ functioned in the earliest biochemical pathways including in those regulating genomic stability $[1-3,11-13,17,52-58]$. 


\section{2. $\mathrm{H}_{2} \mathrm{~S}$ and the DNA Damage Response}

The DNA damage response (DDR) comprises a complex network of cellular pathways that cooperatively detect DNA damage, signals its presence, and promotes DNA repair, maintaining genomic stability [1-3]. Phylogenomic analyses indicate that many elements of the Eukaryotic DDR are ancient, appearing in the first Metazoa and subsequently undergoing evolutionary diversification [59].

Extensive evidence indicates that $\mathrm{H}_{2} \mathrm{~S}$ affects cell DNA stability, impinging on the DDR and cell viability. For example, when the nuclei from Chinese hamster ovary cells were treated $2 \mathrm{~h}$ with $1 \mu \mathrm{M} \mathrm{Na}_{2} \mathrm{~S}$, they exhibited significant DNA damage that was attenuated by treatment with the antioxidant butyl-hydroxyanisole [60]. Treatment of two glioblastoma cell lines with a high amount of $\mathrm{Na}_{2} \mathrm{~S}(476 \mu \mathrm{M})$ for $4 \mathrm{~h}$, increased DNA damage, oxidative stress levels, and increased $\gamma-\mathrm{H} 2 \mathrm{AX}$ foci formation [61]. Additionally, treatment of human intestinal epithelial cells with very high (1-2 $\mathrm{mM}) \mathrm{Na}_{2} \mathrm{~S}$ induced DNA breaks as measured by the comet assay [62]. Similarly, human lung fibroblasts treated $12 \mathrm{~h}$ with $10 \mu \mathrm{M} \mathrm{NaHS}$ showed micronuclei formation, increased p21, p53, Bax, cytochrome c, Ku-70 and Ku-80 expression, and a $\mathrm{G}_{1}$ checkpoint response [63]. These studies implicate $\mathrm{H}_{2} \mathrm{~S}$ in the DDR as; (1) broken DNA activates the DDR, (2) $\gamma$-H2AX foci formation requires the activities of the DDR proteins ATM, ATR, and DNA-PK, (3) the Ku70/Ku80 heterodimer associates with DNA-PK to promote DNA repair, and (4) the ATM kinase is required for the oxidative stress-induced $G_{1}$ checkpoint response and rapid p53 induction [1-3,64].

Other studies have shown that $\mathrm{H}_{2} \mathrm{~S}$ can increase/preserve DNA stability. For example, in a murine model, a unilateral nephrectomy with contralateral ureteral obstruction suppressed $\mathrm{H}_{2} \mathrm{~S}$ kidney levels and caused more DNA damage in CSE deficient mice compared to wild-type mice, indicating that CSE expression plays a role in maintaining DNA stability upon ischemia/reperfusion injury [65]. Additionally, daily injection of the $\mathrm{H}_{2} \mathrm{~S}$ donor diallyl sulfide intraperitoneally into female rats at $50 \mathrm{mg} / \mathrm{kg}$ induced p53, Gadd45a, PCNA, and DNA polymerase $\delta$ in their breast tissue, suggesting that $\mathrm{H}_{2} \mathrm{~S}$ enhances breast tissue DNA repair capacity [66]. Interestingly, exogenous $\mathrm{H}_{2} \mathrm{~S}$ also affects the mitochondrial genome. For example, CSE deficient murine smooth muscle and aortic tissue showed reduced mitochondrial DNA copy numbers, mitochondrial content, mitochondrial-specific mRNAs (MT-CO1, CytB, and Atp 6), and mitochondrial transcription factor A (TFAM) mRNA and protein expression, and it elevated DNA methyltransferase 3A (Dnmt3a) expression, accompanied by increased global DNA methylation with increased TFAM promoter methylation [67]. Treatment with 30 and $60 \mu \mathrm{M} \mathrm{NaSH}$ for $48 \mathrm{~h}$ reversed these effects, with increased mitochondrial marker expression (mitochondrial DNA copy numbers, mRNAs, and mitochondrial content) and decreased Dnmt3a and TFAM promoter methylation, increasing TFAM expression [67]. This study indicates that CSE-derived $\mathrm{H}_{2} \mathrm{~S}$ plays an important role in the maintenance of mitochondrial function and genomic stability. Lastly, 30-100 nM concentrations of AP39, a mitochondria-targeted $\mathrm{H}_{2} \mathrm{~S}$ donor, increased endothelial cell $\mathrm{H}_{2} \mathrm{~S}$ levels and stimulated mitochondrial electron transport and bioenergetic functions. Treatment of the endothelial cells with oxidative stress increased reactive oxygen species (ROS), reduced cell viability, suppressed cellular bioenergetics, and increased mitochondrial DNA damage, events reversed by $100 \mathrm{nM} \mathrm{AP39}$ treatment [68]. Taken together, these studies indicate that under different conditions $\mathrm{H}_{2} \mathrm{~S}$ can increase DNA damage or suppress it and also impinges on the DDR. A caveat to keep in mind is that many experimental procedures in these studies used high concentrations of $\mathrm{H}_{2} \mathrm{~S}$ donors that are likely non-physiologic [61,62]. Additionally, many studies of $\mathrm{H}_{2} \mathrm{~S}$ biology use $\mathrm{H}_{2} \mathrm{~S}$ synthesis inhibitors that have low specificity, complicating experimental result interpretation (reviewed in [69]).

\section{4. $\mathrm{H}_{2} \mathrm{~S}$ and Mitochondrial DNA Repair}

The mitochondria are the major cellular site for ROS generation, and the mitochondrial genome is subject to significant DNA, protein, and lipid oxidative damage [70]. Mitochondrial DNA repair is distinct from and, in general, less complex than the nuclear DNA repair 
systems. For example, base-excision repair (BER) predominates, while nucleotide excision repair (NER) is absent [5,71]. Moreover, mitochondrial genomes with double-stranded DNA (dsDNA) breaks are usually rapidly degraded, leading to a drop in genome copy number, which are replaced through non-cleaved genome replication, often leading to a shift in heteroplasmy [5]. A role for $\mathrm{H}_{2} \mathrm{~S}$ in mitochondrial function is well established with, for example, the mitochondrial $\mathrm{H}_{2} \mathrm{~S}$ donor AP39 promoting mitochondrial bioenergetics and genomic stability and in the face of exogenous oxidants [68]. Additionally, in ovarian cancer cell lines, CBS expression maintains mitofusin-2 expression, with CBS knockdown lowering mitofusin-2 expression, causing mitochondrial fragmentation with a fused spherical morphology and increased unbranched mitochondria [72]. Mitofusin-2 exerts anti-apoptotic effects, and its ablation is lethal in mice [73]. Interestingly, its expression is lower in obesity, diabetes, and in animal models prone to atherosclerosis, and is increased by weight loss and exercise [73].

The apyrimidinic/apurinic endonuclease 1 (APE1), exonuclease G (EXOG), DNA Ligase III (LIG3), and DNA polymerase gamma (Pol $\gamma$ ) play central roles in mitochondrial BER $[4,11,74-76]$. Loss of these proteins has severe often lethal effects. For example, EXOG depletion induces persistent single-stranded DNA breaks leading to apoptosis, while APE1 ablation is embryonic lethal, and its removal by Cre expression causes apoptotic cell death within $24 \mathrm{~h}[74,75]$. In the A549 lung adenocarcinoma cell line, siRNA knockdown of CBS, CSE, or 3-MST or treatment with the CSE-specific inhibitor D, L-propargylglycine (PAG) combined with exogenous oxidative stress significantly increased mitochondrial DNA damage [11]. Interestingly, the interactions of EXOG with APE1, LIG3, and POL were all attenuated with CBS, CSE, or 3-MST knockdown or pharmacologic CBS inhibition by aminooxyacetic acid (AOAA) [11]. The interactions of EXOG with APE1 or LIG3 following AOAA treatment were restored and mitochondrial DNA damage was reduced with AP39 co-treatment, demonstrating that mitochondrial $\mathrm{H}_{2} \mathrm{~S}$ restored these interactions and increased mitochondrial genomic stability [11]. Mass spectrometric analysis revealed that EXOG Cys 76 was sulfhydrated, with the $\mathrm{H}_{2} \mathrm{~S}$ donor NaHS increasing EXOC and APE1 interactions. Mutation of EXOG Cys 76 to alanine lowered its interactions with APE1 and made the interaction insensitive to NaHS treatment [11]. Thus, this elegant study demonstrated that mitochondrial $\mathrm{H}_{2} \mathrm{~S}$ plays a central role in mitochondrial genomic stability and DNA repair.

\section{5. $\mathrm{H}_{2} \mathrm{~S}$ and Nuclear DNA Repair: ATR and MEK1}

\subsection{ATR}

Nuclear DNA repair and the DDR involve at least five major pathways comprising BER, NER, mismatch excision repair, homologous recombination, and non-homologous end joining [1-3]. The ataxia-telangiectasia mutated, and RAD3-related serine/threonine protein kinase (ATR) plays a central role in the DDR, where it stabilizes single-stranded DNA (ssDNA) at stalled replication forks, lowers replication stress, initiates cell cycle checkpoints, and promotes faithful anaphase chromosomal segregation [1-3,12]. Interestingly, increased ATR/phospho-ATR expression is a poor prognostic factor in breast, bladder, and ovarian cancers [77-79]. Analysis of a colon adenocarcinoma cell lines with wild-type and biallelic knock-in hypomorphic ATR Seckel syndrome 1 genes revealed lower cellular $\mathrm{H}_{2} \mathrm{~S}$ levels in the mutant cells compared to the wild type [12]. ATR inhibition with the pharmacologic ATR inhibitor NU6027 also significantly lowered cellular $\mathrm{H}_{2} \mathrm{~S}$ levels in the wild-type but not the mutant cells [12]. Treatment of both cell lines with the CBS/CSE inhibitor $\beta$-cyanoL-alanine suppressed $\mathrm{H}_{2} \mathrm{~S}$ levels in both cell types, demonstrating that cellular $\mathrm{H}_{2} \mathrm{~S}$ levels are regulated by CBS/CSE and ATR, which form separate regulatory foci [12].

Interestingly, ATR activation correlates with serine 435 phosphorylation, an event also required for ATR-XPA dimer formation and subsequent NER [12,80]. Treatment of the colon adenocarcinoma cell lines with $\beta$-cyano-L-alanine increased this phosphorylation, while treatment with the $\mathrm{H}_{2} \mathrm{~S}$ donor diallyl trisulfide significantly suppressed it in the wildtype but not mutant cells. UV light and oxidative stress treatments similarly induced this 
phosphorylation in the wild-type but not mutant cells [12]. Activated ATR phosphorylates the CHK1 kinase serine 345, leading to its activation [1-3,12]. When the cells lines were pretreated with $\beta$-cyano-L-alanine, followed by a low concentration of oxidative stress, oxidative stress-induced $\mathrm{CHK} 1$ phosphorylation increased with $\mathrm{H}_{2} \mathrm{~S}$ synthesis inhibition, an event again not seen in the mutant cells [12]. Lastly, to examine the effects of these events on genomic stability, oxidative stress-induced dsDNA breaks were quantified in both cell types with and without $\mathrm{H}_{2} \mathrm{~S}$ synthesis inhibition by $\beta$-cyano-L-alanine treatment. $\mathrm{H}_{2} \mathrm{~S}$ synthesis inhibition caused low levels of oxidative stress to significantly induce dsDNA breaks, where otherwise they were not increased [12]. The mutant cells also showed increased breaks compare to the wild-type cells [12]. Taken together, these finding indicate that ATR regulates cellular $\mathrm{H}_{2} \mathrm{~S}$ levels and $\mathrm{H}_{2} \mathrm{~S}$, in turn, regulates ATR phosphorylation, ATR kinase activity, and nuclear genomic stability [12].

\subsection{MEK1}

An important initial and required step in the DDR is carried out by poly (ADP-ribose) polymerases (PARPS) that transfer ADP-ribose from $\mathrm{NAD}^{+}$to glutamic acid residues on a protein acceptor, creating ADP-ribose polymers at sights of DNA damage [1-3,81]. These chains function in the recruitment of factors involved in DNA repair such as polymerase $\beta$, XRCC1, and ligase III $\alpha[1-3,82]$. PARP activation is tightly regulated by a cascade of kinases including the MEK/ERK signaling pathway [1-3,82-84]. In an interesting study, treatment of human endothelial cells for $2 \mathrm{~h}$ with $10 \mu \mathrm{M}$ NaHS increased MEK1 Cys $341 \mathrm{~S}$-sulfhydration. This event resulted in ERK1/2 phosphorylation and its subsequent translocation into the nucleus, where it activated PARP-1 through a direct interaction [13]. Mutation of MEK1 Cys 341 to Gly blocked these events.

Next HEK293 cells were treated with methyl methanesulfonate (MMS), which induces ssDNA and dsDNA breaks and activates PARP-1 activity, with PARP-1 then recruiting XRCC1 and DNA ligase III to initiate DNA repair [13,83-85]. MMS treatment of the HEK293 cells resulted in MEK1 Cys 341 S-sulfhydration, but not in cells carrying the Gly 341 mutated MEK1 [13]. This S-sulfhydration increased in CSE over-expressing HEK293 cells. Lastly, application of MMS to human endothelial cells, with and without co-treatment with $0.1-10 \mu \mathrm{M}$ NaHS, increased PARP-1 activity in a dose-dependent manner, with PARP1 activation detectable at $5 \mathrm{~min}$ with NaHS treatment and only at 30 min without NaHS treatment [13]. NaHS treatment also reduced the amount of HEK293 cell DNA damage and increased the amounts of XRCC1 and DNA ligase III recruited [13]. This study indicates that CSE-generated $\mathrm{H}_{2} \mathrm{~S}$ acts as a DNA damage protectant, S-sulfhydrating MEK1 Cys 341, activating ERK1/2 and PARP-1 to repair DNA damage [13].

These studies on the roles of ATR and MEK1 in nuclear DNA repair demonstrate that $\mathrm{H}_{2} \mathrm{~S}$ plays an important and, as yet, poorly defined role in nuclear DNA repair regulation [12,13]. Interestingly, low cellular $\mathrm{H}_{2} \mathrm{~S}$ concentrations activate ATR, as measured by its kinase activity towards CHK1 [12]. Conversely, MEK1 activity in DNA repair is increased with increased $\mathrm{H}_{2} \mathrm{~S}$ concentrations, as supplied either by exogenous $\mathrm{NaHS}$ or increased CSE expression [13]. Thus, these studies imply that nuclear DNA repair is likely modulated by both increased and decreased cellular $\mathrm{H}_{2} \mathrm{~S}$ concentrations [12,13]. Additionally, CBS and CSE knockdown both attenuated the mitochondrial interactions of EXOG with APE1, LIG3, and POL $\gamma$, implying that ATR may also indirectly regulate mitochondrial BER [11,12].

\section{6. $\mathrm{H}_{2} \mathrm{~S}$, Autophagy, and the DDR}

Recently, Jiang et al. employed a high-content screen of $\sim 12,000$ with diversified chemical structures and molecular targets, screening for compounds that increased cellular $\mathrm{H}_{2} \mathrm{~S}$ expression $>1.4$ with a concomitant $>50 \%$ cell survival compared to DMSO treated controls [85]. Interestingly, the largest activating compound class screened consisted of genotoxic compounds, with the most active compounds being the topoisomerase inhibitors irinotecan and teniposide, the nucleoside analog trifluridine, and bleomycin. Additionally, 
UVC light, ionizing radiation, and NER deficiency were also strong intracellular $\mathrm{H}_{2} \mathrm{~S}$ inducers. Intriguingly, teniposide and UVC treatment increased the cellular sulfane sulfur fraction, indicating that the larger sulfur pool was also altered by genotoxic stress [85]. To further characterize the role of the DDR in these responses, immortalized murine embryonic fibroblasts (MEFs), with and without PARP-1 expression, were treated with UVC or teniposide [85]. PARP-1 loss significantly decreased $\mathrm{H}_{2} \mathrm{~S}$ induction by either agent, strongly implicating a role for early DDR events in $\mathrm{H}_{2} \mathrm{~S}$ induction [85].

Autophagy is a significant part of the DDR [86]. In MEFs knockdown of ATG5 and ATG7, two autophagy regulators, attenuated LC3I to LC3II conversion (also an autophagy marker) initiated by teniposide. Importantly, this was accompanied by a concomitant decrease in $\mathrm{H}_{2} \mathrm{~S}$ induction, linking $\mathrm{H}_{2} \mathrm{~S}$ induction, the DDR, and autophagy [85]. ATG5 knockout MEF viability (which showed teniposide hypersensitivity) was partially rescued from teniposide toxicity by concomitant AP39 treatment, indicating that $\mathrm{H}_{2} \mathrm{~S}$ plays a cellular protective role in genotoxic exposure [85]. AMPK is activated by PARP-1 and is another DDR mediator [86]. In AMPK, double $\alpha 1 / \alpha 2$ subunit knockout MEFs, $\mathrm{H}_{2} \mathrm{~S}$ and autophagy induction with teniposide were also attenuated, again consistent with a requirement for autophagy in maximal $\mathrm{H}_{2} \mathrm{~S}$ induction by genoclastic agents [85].

Lastly, teniposide treatment significantly induced CSE mRNA and protein in MEFs. CSE expression ablation resulted in a small but significant decrease in cellular $\mathrm{H}_{2} \mathrm{~S}$ levels with teniposide treatment, indicating a possible role of CSE in the DDR [85]. Under genotoxic stress CSE mRNA is induced by the ATF4 transcription factor [87]. In MEFs, ATF4 expression ablation resulted in both attenuated CSE induction and lowered cellular $\mathrm{H}_{2} \mathrm{~S}$ levels following teniposide treatment. Additionally, treatment of wild-type and ATG5 knockout MEFs with PAG decreased teniposide-induced $\mathrm{H}_{2} \mathrm{~S}$ in both cell types. These results suggest an additive role for ATF4-mediated CSE expression and autophagy in $\mathrm{H}_{2} \mathrm{~S}$ induction upon genotoxic stress [85]. These interactions are summarized in Figure 1.

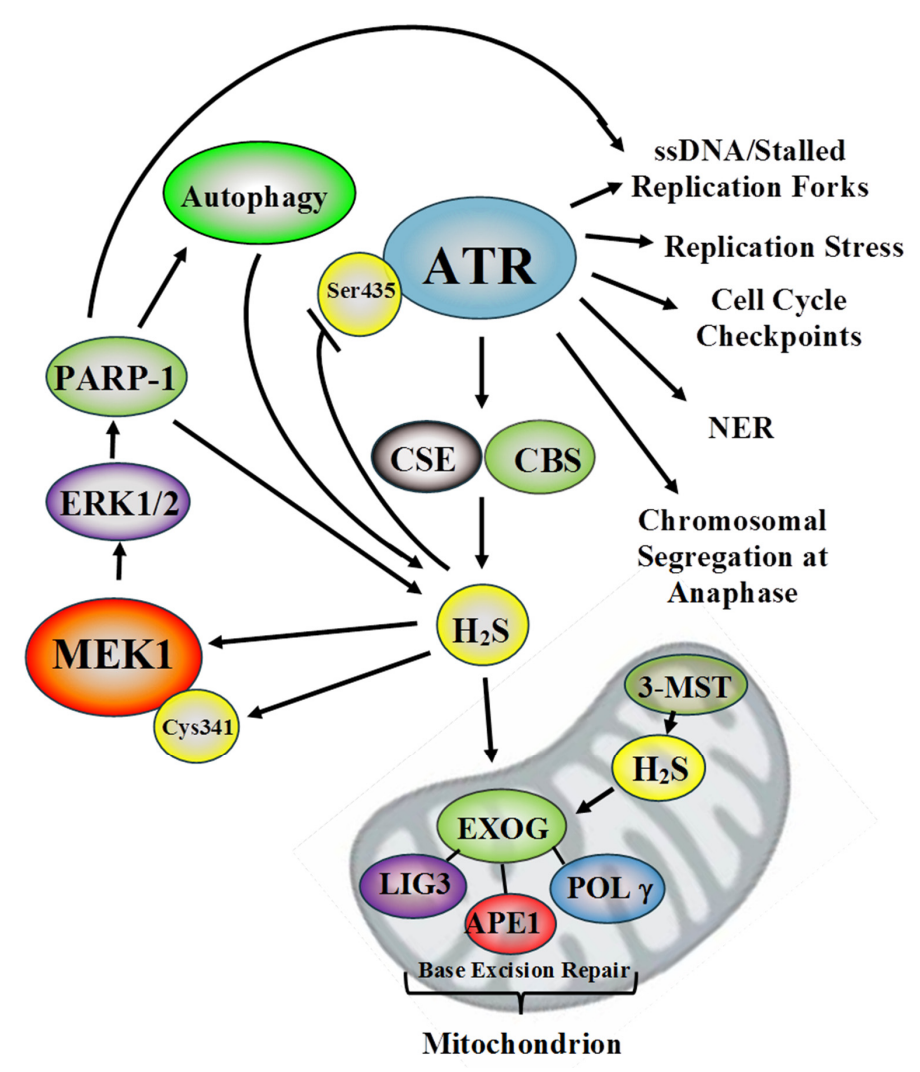

Figure 1. A summary of known pathways by which $\mathrm{H}_{2} \mathrm{~S}$ regulates mitochondrial and nuclear DNA repair integrated into one model $[11-13,85]$. 


\section{Conclusions and Future Directions: Cancer Therapy and Cardiovascular Disease}

The role of $\mathrm{H}_{2} \mathrm{~S}$ in DNA repair and the DDR is an established, but as yet under researched area with few studies on the subject $[11-13,85]$. Due to the importance of genomic stability maintenance, DNA repair, and $\mathrm{H}_{2} \mathrm{~S}$ in normal and pathophysiology, a better understanding of this area will undoubtedly lead to a greater understanding of the molecular pathology underlying many human diseases. For example, increased DNA damage in the vasculature is a major cardiovascular disease risk factor, and $\mathrm{H}_{2} \mathrm{~S}$ is a major regulator of cardiovascular functions $[14,88]$. However, there is relatively little data on the role of the DDR and DNA repair in the cardiovascular system, although intriguingly murine models of defective NER show premature vascular senescence, increased vascular stiffness, and elevated blood pressure [89]. As the ATR kinase regulates NER, there may be an as yet undiscovered role for ATR in vascular diseases [1-3,12,89]. Additionally, the DDR protein ATM plays a poorly defined role in cardiovascular disease, with individuals and mice with only one functional ATM gene showing elevated cardiovascular disease, while a high fat diet suppresses ATM protein expression in wild-type animals [90,91]. A role for ATM in $\mathrm{H}_{2} \mathrm{~S}$ metabolism has not yet been identified.

Increased $\mathrm{H}_{2} \mathrm{~S}$ synthesis and CBS, CSE, and/or 3-MST expression promote cancer progression in several human malignancies, and $\mathrm{H}_{2} \mathrm{~S}$ synthesis inhibitors have been proposed as a cancer treatment $[5,11,12,17,69,92,93]$. In addition, ATR inhibitors are showing promise in phase I and II clinical trials for lung, ovarian, cervical, urothelial, and advanced sold tumors [93]. Since ATR inhibition lowers cellular $\mathrm{H}_{2} \mathrm{~S}$ concentrations, this may be an unexamined aspect of ATR inhibition in cancer therapeutics [12,92,93]. Similarly, lowered cellular $\mathrm{H}_{2} \mathrm{~S}$ levels with ATR inhibition could, in turn, lower MEK1 and EXOG sulfhydration and activation, attenuating mitochondrial DNA repair and nuclear DNA repair mediated by the MEK1-ERK1/2-PARP-1 axis [11-13]. Interestingly, ATR inhibition increases the effectiveness of PARP inhibitors in cancer therapy, supporting this hypothesis [94-96]. Thus, $\mathrm{H}_{2} \mathrm{~S}$ may form a molecular link uniting different aspects of DNA repair (summarized in Figure 1).

Previously, we reviewed the role of $\mathrm{H}_{2} \mathrm{~S}$ in DNA repair with an emphasis on ATR function [69]. Here, we extended this review, as current data strongly implicate a role for other DDR proteins, especially ATM in $\mathrm{H}_{2} \mathrm{~S}$ regulation [1-3,62-64]. Additionally, the data by Jiang et al. demonstrate that $\mathrm{H}_{2} \mathrm{~S}$, autophagy, and the DDR are intricately interconnected, further highlighting the function of $\mathrm{H}_{2} \mathrm{~S}$ in the most basic functions regulating cell survival [85]. Support for this also comes from the known roles of the DDR proteins in regulating autophagy $[85,97]$.

ATR, ATM, and DNA-PK are central to the DRR and DNA repair $[1-3,95,96]$. All three proteins share extensive sequence and substrate overlap, and synthetic lethal relationships exist between them [1-3,96]. Moreover, all three proteins regulate autophagy and mitochondrial function and viability [97-100]. These observations, combined with the ancient and parallel origins of $\mathrm{H}_{2} \mathrm{~S}$ biochemistry and DNA repair, and with $\mathrm{H}_{2} \mathrm{~S}$ now linked to mitochondrial and nuclear DNA repair, suggest that ATM and DNA-PK may also regulate aspects of $\mathrm{H}_{2} \mathrm{~S}$ metabolism [1-3,11-13,17,52-58]. Although only hypotheses, these ideas could be easily tested. In summary, the role of $\mathrm{H}_{2} \mathrm{~S}$ in the regulation of the DDR and DNA repair is a new and exciting area of inquiry and should give useful and profound insights into normal and pathophysiology.

Author Contributions: Conceptualization and research were performed by all the authors, R.E.S., C.G.K., Y.L., and G.E.G., C.G.K. and R.E.S. wrote the main portion of the manuscript. All authors have read and agreed to the published version of the manuscript.

Funding: This work supported by grants from the A-T Children's Project and an intramural research support grant from Louisiana Health Sciences Shreveport, Center for Cardiovascular Diseases and Sciences. Lastly, this work was supported by an Institutional Development Award (IDeA) from the National Institutes of General Medical Sciences of the NIH under grant numbers GM121307 and HL149264 from the National Heart, Lung, and Blood Institute to C.G.K. 
Acknowledgments: We would like to thank Lisa LaChance, MBA, for her help in the assembly and proofreading of this manuscript.

Conflicts of Interest: The authors declare no conflict of interest.

\section{References}

1. Hanawalt, P.C. Historical perspective on the DNA damage response. DNA Repair 2015, 36, 2-7. [CrossRef] [PubMed]

2. Saldivar, J.C.; Cortez, D.; Karlene, A.; Cimprich, K.A. The essential kinase ATR: Ensuring faithful duplication of a challenging genome. Nat. Rev. Mol. Cell Biol. 2017, 18, 622-636. [CrossRef]

3. Hustedt, N.; Durocher, D. The control of DNA repair by the cell cycle. Nat. Cell Biol. 2016, 19, 1-9. [CrossRef] [PubMed]

4. Houten, B.V.; Hunter, S.E.; Meyer, J.N. Mitochondrial DNA damage induced autophagy, cell death, and disease. Front. Biosci. 2016, 21, 42-54. [CrossRef]

5. Fu, Y.; Tigano, M.; Agnel Sfeir, A. Safeguarding mitochondrial genomes in higher eukaryotes. Nat. Struct. Mol. Biol. 2020, 27, 687-695. [CrossRef]

6. Mills, E.L.; Kelly, B.; O’Neill, L.A.J. Mitochondria are the powerhouses of immunity. Nat. Immunol. 2017, 18, 488-498. [CrossRef]

7. West, A.P.; Khoury-Hanold, W.; Staron, M.; Tal, M.C.; Pineda, C.M.; Lang, S.M.; Smith, M.B.; Duguay, B.A.; Raimundo, N.; Macduff, D.; et al. Mitochondrial DNA stress primes the antiviral innate immune response. Nature 2015, 520, 553-557. [CrossRef]

8. Wang, R. Two's company, three's a crowd: Can $\mathrm{H}_{2} \mathrm{~S}$ be the third endogenous gaseous transmitter? FASEB J. 2002, 16, 1792-1798. [CrossRef] [PubMed]

9. Nagy, P. Mechanistic chemical perspective of hydrogen sulfide signaling. Methods Enzymol. 2015, 554, 3-29. [CrossRef]

10. Abe, K.; Kimura, H. The possible role of hydrogen sulfide as an endogenous neuromodulator. J. Neurosci. 1996, 16, 1066-1071. [CrossRef] [PubMed]

11. Szczesny, B.; Marcatti, M.; Zatarain, J.R.; Druzhyna, N.; Wiktorowicz, J.E.; Nagy, P.; Hellmich, M.R.; Szabo, C. Inhibition of hydrogen sulfide biosynthesis sensitizes lung adenocarcinoma to chemotherapeutic drugs by inhibiting mitochondrial DNA repair and suppressing cellular bioenergetics. Sci. Rep. 2016, 6, 36125. [CrossRef]

12. Chen, J.; Shen, X.; Pardue, S.; Meram, A.T.; Rajendran, S.; Ghali, G.; Kevil, C.G.; Shackelford., R.E. The Ataxia telangiectasiamutated and Rad3-related protein kinase regulates cellular hydrogen sulfide concentrations. DNA Repair 2019, 73, 55-63. [CrossRef]

13. Zhao, Y.; Ju, S.; Li, Z.; Altaany, R.; Wang, G.; Yang, G. S-sulfhydration of MEK1 leads to PARP-1 activation and DNA damage repair. EMBO Rep. 2014, 15, 792-800. [CrossRef] [PubMed]

14. Kolluru, G.; Shen, X.; Kevil, C.G. Reactive sulfur species: A new redox player in cardiovascular pathophysiology. Arterioscler. Thromb. Vasc. Biol. 2020, 40, 874-884. [CrossRef]

15. Głowacka, U.; Brzozowski, T.; Magierowski, M. Synergisms, discrepancies and interactions between hydrogen sulfide and carbon monoxide in the gastrointestinal and digestive system physiology, pathophysiology and pharmacology. Biomolecules 2020, 10, 445. [CrossRef]

16. Kumar, M.; Sandhir, R. Hydrogen sulfide in physiological and pathological mechanisms in brain. CNS Neurol. Disord. Drug Targets 2018, 17, 654-670. [CrossRef] [PubMed]

17. Shackelford, R.E.; Mohammad, I.Z.; Meram, A.T.; Kim, D.; Alotaibi, F.; Patel, S.; Ghali, G.; Kevil, C.G. Molecular functions of hydrogen sulfide in cancer. Pathophysiology 2021, 28, 437-456. [CrossRef]

18. Reiffenstein, R.J.; Hulbert, W.C.; Roth, S.H. Toxicology of hydrogen sulfide. Annu. Rev. Pharmacol. Toxocol. 1992, 32, 109-134. [CrossRef]

19. Kolluru, G.K.; Shen, X.; Bir, S.C.; Kevil, C.G. Hydrogen sulfide chemical biology: Pathophysiological roles and detection. Nitric Oxide 2013, 35, 5-20. [CrossRef]

20. Nicholson, R.A.; Roth, S.H.; Zhang, A.; Brookes, J.; Skrajny, B.; Bennington, R. Inhibition of respiratory and bioenergetic mechanisms by hydrogen sulfide in mammalian brain. J. Toxicol. Environ. Health A 1998, 54, 491-507. [CrossRef]

21. Warenycia, M.W.; Smith, K.A.; Blashko, C.S.; Kombian, S.B.; Reiffenstein, R.J. Monoamine oxidase inhibition as a sequel of hydrogen sulfide intoxication: Increases in brain catecholamine and 5-hydroxytryptamine levels. Arch. Toxicol. 1989, 63, 131-136. [CrossRef] [PubMed]

22. Cuevasanta, E.; Denicola, A.; Alvarez, B.; Moller, M.N. Solubility and permeation of hydrogen sulfide in lipid membranes. PLoS ONE 2012, 7, e34562. [CrossRef] [PubMed]

23. Jennings, M.L. Transport of $\mathrm{H}_{2} \mathrm{~S}$ and $\mathrm{HS}^{-}$across the human red blood cell membrane: Rapid $\mathrm{H}_{2} \mathrm{~S}$ diffusion and AE1-mediated $\mathrm{Cl}^{-}$/HS ${ }^{-}$exchange. Am. J. Physiol. Cell Physiol. 2013, 305, C941-C950. [CrossRef]

24. Czyzewski, B.K.; Wang, D.N. Identification and characterization of a bacterial hydrosulphide ion channel. Nature 2012, 483, 494-497. [CrossRef]

25. Kimura, Y.; Kimura, H. Hydrogen sulfide protects neurons from oxidative stress. FASEB J. 2004, 18, 1165-1167. [CrossRef]

26. Whiteman, M.; Armstrong, J.S.; Chu, S.H.; Jia-Ling, S.; Wong, B.S.; Cheung, N.S.; Halliwell, B.; Moore, P.K. The novel neuromodulator hydrogen sulfide: An endogenous peroxynitrite 'scavenger'? J. Neurochem. 2004, 90, 765-768. [CrossRef]

27. Xie, Z.Z.; Liu, Y.; Bian, J.S. Hydrogen sulfide and cellular redox homeostasis. Oxid. Med. Cell. Longev. 2016, $2016,6043038$. [CrossRef] [PubMed] 
28. Vitvitsky, V.; Kabil, O.; Banerjee, R. High turnover rates for hydrogen sulfide allow for rapid regulation of its tissue concentrations. Antioxid. Redox Signal. 2012, 17, 22-31. [CrossRef] [PubMed]

29. Carballal, S.; Trujillo, M.; Cuevasanta, E.; Bartesaghi, S.; Möller, M.N.; Folkes, L.K.; García-Bereguiaín, M.A.; Gutiérrez-Merino, C.; Wardman, P.; Denicola, A.; et al. Reactivity of hydrogen sulfide with peroxynitrite and other oxidants of biological interest. Free Radic. Biol. Med. 2011, 50, 196-205. [CrossRef] [PubMed]

30. Orlowski, A. Hydroghne sulfur comme produit de certaines bacteries. J. Med. Milit. Russe 1897, 11, 528.

31. Calvert, J.W.; Coetzee, W.A.; Lefer, D.J. Novel insights into hydrogen sulfide-mediated cytoprotection. Antioxid. Redox Signal 2010, 12, 1203-1217. [CrossRef]

32. Hosoki, R.; Matsuki, N.; Kimura, H. The possible role of hydrogen sulfide as an endogenous smooth muscle relaxant in synergy with nitric oxide. Biochem. Biophys. Res. Commun. 1997, 237, 527-531. [CrossRef] [PubMed]

33. Shibuya, N.; Tanaka, M.; Yoshida, M.; Ogasawara, Y.; Togawa, T.; Ishii, K.; Kimura, H. 3-Mercaptopyruvate sulfurtransferase produces hydrogen sulfide and bound sulfane sulfur in the brain. Antioxid. Redox Signal. 2009, 11, 703-714. [CrossRef]

34. Sbodio, J.I.; Snyder, S.H.; Paul, B.D. Regulators of the transsulfuration pathway. Br. J. Pharmacol. 2019, 176, 583-593. [CrossRef]

35. Braunstein, A.E.; Goryachenkova, E.V.; Tolosa, E.A.; Willhardt, I.H.; Yefremova, L.L. Specificity and some other properties of liver serine sulphhydrase: Evidence for its identity with cystathionine-synthase. Biochim. Biophys. Acta 1971, 242, 247-260. [CrossRef]

36. Singh, S.; Madzelan, P.; Stasser, J.; Weeks, C.L.; Becker, D.; Spiro, T.G.; Penner-Hahn, J.; Banerjee, R. Modulation of the heme electronic structure and cystathionine beta-synthase activity by second coordination sphere ligands: The role of heme ligand switching in redox regulation. J. Inorg. Biochem. 2009, 103, 689-697. [CrossRef] [PubMed]

37. Jhee, K.H.; Kruger, W.D. The role of cystathionine beta-synthase in homocysteine metabolism. Antioxid. Redox Signal. 2005, 7, 813-822. [CrossRef]

38. Chiku, T.; Padovani, D.; Zhu, W.; Singh, S.; Vitvitsky, V.; Banerjee, R. $\mathrm{H}_{2} \mathrm{~S}$ biogenesis by human cystathionine gamma-lyase leads to the novel sulfur metabolites lanthionine and homolanthionine and is responsive to the grade of hyperhomocysteinemia. J. Biol. Chem. 2009, 284, 11601-11612. [CrossRef] [PubMed]

39. Nagahara, N.; Ito, T.; Kitamura, H.; Nishino, T. Tissue and subcellular distribution of mercaptopyruvate sulfurtransferase in the rat: Confocal laser fluorescence and immunoelectron microscopic studies combined with biochemical analysis. Histochem. Cell Biol. 1998, 110, 243-250. [CrossRef]

40. Shibuya, N.; Koike, S.; Tanaka, M.; Ishigami-Yuasa, M.; Kimura, Y.; Ogasawara, Y.; Fukui, K.; Nagahara, N.; Kimura, H. A novel pathway for the production of hydrogen sulfide from D-cysteine in mammalian cells. Nat. Commun. 2013, 4, 1366. [CrossRef]

41. Yang, J.; Minkler, P.; Grove, D.; Wang, R.; Willard, B.; Dweik, R.; Hine, C. Non-enzymatic hydrogen sulfide production from cysteine in blood is catalyzed by iron and vitamin B6. Commun. Biol. 2019, 2, 194. [CrossRef]

42. Shen, X.; Carlström, M.; Borniquel, S.; Jädert, C.; Kevil, C.G.; Lundberg, J.O. Microbial regulation of host hydrogen sulfide bioavailability and metabolism. Free Radic. Biol. Med. 2013, 60, 195-200. [CrossRef]

43. Lagoutte, E.; Mimoun, S.; Andriamihaja, M.; Chaumontet, C.; Blachier, F.; Bouillaud, F. Oxidation of hydrogen sulfide remains a priority in mammalian cells and causes reverse electron transfer in colonocytes. Biochim. Biophys. Acta 2010, 1797, $1500-1511$. [CrossRef]

44. Rose, P.; Moore, P.K.; Zhu, Y.Z. $\mathrm{H}_{2} \mathrm{~S}$ biosynthesis and catabolism: New insights from molecular studies. Cell. Mol. Life Sci. 2017, 74, 1391-1412. [CrossRef]

45. Jackson, M.R.; Melideo, S.L.; Jorns, M.S. Human sulfide:quinone oxidoreductase catalyzes the first step in hydrogen sulfide metabolism and produces a sulfane sulfur metabolite. Biochemistry 2012, 51, 6804-6815. [CrossRef]

46. Maseda, C.; Hayakawa, A.; Okuda, K.; Asari, M.; Tanaka, H.; Yamada, H.; Jin, S.; Horioka, K.; Matoba, K.; Shiono, H.; et al. Liquid chromatography-tandem mass spectrometry method for the determination of thiosulfate in human blood and urine as an indicator of hydrogen sulfide poisoning. Leg. Med. 2017, 24, 67-74. [CrossRef] [PubMed]

47. Goubern, M.; Andriamihaja, M.; Nübel, T.; Blachier, F.; Bouillaud, F. Sulfide, the first inorganic substrate for human cells. FASEB J. 2007, 21, 1699-1706. [CrossRef]

48. Kimura, Y.; Toyofuku, Y.; Koike, S.; Shibuya, N.; Nagahara, N.; Lefer, D.; Ogasawara, Y.; Kimura, H. Identification of $\mathrm{H}_{2} \mathrm{~S}_{3}$ and $\mathrm{H}_{2} \mathrm{~S}$ produced by 3-mercaptopyruvate sulfurtransferase in the brain. Sci. Rep. 2015, 5, 14774. [CrossRef] [PubMed]

49. Fukuto, J.M.; Ignarro, L.J.; Nagy, P.; Wink, D.A.; Kevil, C.G.; Feelisch, M.; Cortese-Krott, M.M.; Bianco, C.L.; Kumagai, Y.; Hobbs, A.J.; et al. Biological hydropersulfides and related polysulfides-A new concept and perspective in redox biology. FEBS Lett. 2018, 592, 2140-2152. [CrossRef] [PubMed]

50. Dodd, M.S.; Papineau, D.; Grenne, T.; Slack, J.F.; Rittner, M.; Pirajno, F.; O'Neil, J.; Little, C.T.S. Evidence for early life in Earth's oldest hydrothermal vent precipitates. Nature 2017, 543, 60-64. [CrossRef]

51. Nutman, A.P.; Bennett, V.C.; Friend, C.R.L.; Kranendonk, M.J.V.; Chivas, A.R. Rapid emergence of life shown by discovery of 3,700-million-year-old microbial structures. Nature 2016, 537, 535-538. [CrossRef]

52. Mißbach, H.; Duda, J.P.; van den Kerkhof, A.M.; Lüders, V.; Pack, A.; Reitner, J.M.; Thiel, V. Ingredients for microbial life preserved in 3.5 billion-year-old fluid inclusions. Nat. Commun. 2021, 12, 1101. [CrossRef]

53. Martin, W.; Baross, J.; Kelley, D.; Russell, M.J. Hydrothermal vents and the origin of life. Nat. Rev. Microbiol. 2008, 6, 805-814. [CrossRef]

54. Kasting, J.F. Earth's early atmosphere. Science 1993, 259, 920-926. [CrossRef] [PubMed] 
55. Tabibzadeh, S. Nature creates, adapts, protects and sustains life using hydrogen sulfide. Front. Biosci. 2016, 21, 528-560. [CrossRef] [PubMed]

56. DeLeon, E.R.; Gao, Y.; Huang, E.; Arif, M.; Arora, N.; Divietro, A.; Patel, S.; Olson, K.R. A case of mistaken identity: Are reactive oxygen species actually reactive sulfide species? Am. J. Physiol. Regul. Integr. Comp. Physiol. 2016, 310, R549-R560. [CrossRef]

57. Tetz, V.V.; Tetz, G.V. A new biological definition of life. Biomol. Concepts 2020, 11, 1-6. [CrossRef] [PubMed]

58. Aroca, A.; Gotor, C.; Bassham, D.C.; Romero, L.C. Hydrogen sulfide: From a toxic molecule to a key molecule of cell life. Antioxidants 2020, 9, 621. [CrossRef]

59. Brown, J.R.; Auger, K.R. Phylogenomics of phosphoinositide lipid kinases: Perspectives on the evolution of second messenger signaling and drug discovery. BMC Evol. Biol. 2011, 11, 4. [CrossRef]

60. Attene-Ramos, M.S.; Wagner, E.D.; Gaskins, H.R.; Plewa, M.J. Hydrogen sulfide induces direct radical-associated DNA damage. Mol. Cancer Res. 2007, 5, 455-459. [CrossRef]

61. Xiao, A.Y.; Maynard, M.R.; Piett, C.G.; Nagel, Z.D.; Alexander, J.S.; Kevil, C.G.; Berridge, M.V.; Pattillo, C.B.; Rosen, L.R.; Miriyala, S.; et al. Sodium sulfide selectively induces oxidative stress, DNA damage, and mitochondrial dysfunction and radiosensitizes glioblastoma (GBM) cells. Redox Biol. 2019, 26, 101220. [CrossRef]

62. Attene-Ramos, M.S.; Nava, G.M.; Muellner, M.G.; Wagner, E.D.; Plewa, M.J.; Gaskins, R.S. DNA damage and toxicogenomic analyses of hydrogen sulfide in human intestinal epithelial FHs 74 Int cells. Environ. Mol. Mutagen. 2010, 51, 304-314. [CrossRef]

63. Baskar, R.; Li, L.; Moore, P.K. Hydrogen sulfide-induces DNA damage and changes in apoptotic gene expression in human lung fibroblast cells. FASEB J. 2007, 21, 247-255. [CrossRef]

64. Shackelford, R.E.; Innes, C.L.; Sieber, S.O.; Heinloth, A.N.; Leadon, S.; Paules, R.S. The Ataxia telangiectasia gene product is required for oxidative stress-induced G1 and G2 checkpoint function in human fibroblasts. J. Biol. Chem. 2001, 276, 21951-21959. [CrossRef]

65. Han, S.J.; Noh, M.R.; Jung, J.M.; Ishii, I.; Yoo, J.; Kim, J.I.; Park, K.M. $\mathrm{H}_{2}$ S-producing cystathionine $\gamma$-lyase is critical in the progression of kidney fibrosis. Free Radic. Biol. Med. 2017, 112, 423-432. [CrossRef]

66. Green, M.; Newell, O.; Aboyade-Cole, A.; Darling-Reed, S.; Thomas, R.D. Diallyl sulfide induces the expression of nucleotide excision repair enzymes in the breast of female ACI rats. Toxicol. Lett. 2007, 168, 40-44. [CrossRef]

67. Li, S.; Yang, G. Hydrogen sulfide maintains mitochondrial DNA replication via demethylation of TFAM. Antioxid. Redox Signal. 2015, 32, 630-642. [CrossRef] [PubMed]

68. Szczesny, B.; Módis, K.; Yanagi, K.; Coletta, C.; Trionnaire, S.L.; Perry, A.; Wood, M.E.; Whiteman, M.; Szabo, C. AP39, a novel mitochondria-targeted $\mathrm{H}_{2} \mathrm{~S}$ donor, stimulates cellular bioenergetics, exerts cytoprotective effects and protects against the loss of mitochondrial DNA integrity in oxidatively stressed endothelial cells in vitro. Nitric Oxide 2014, 41, 120-130. [CrossRef] [PubMed]

69. Shackelford, R.; Ozluk, E.; Islam, M.K.; Hopper, B.; Meram, A.; Ghali, G.; Kevil, C.G. Hydrogen sulfide and DNA repair. Redox. Biol. 2021, 38, 101675. [CrossRef] [PubMed]

70. Cadenas, E.; Davies, K.J. Mitochondrial free radical generation, oxidative stress, and aging. Free Radic. Biol. Med. 2000, 29, 222-230. [CrossRef]

71. Kazak, L.; Reyes, A.; Holt, I.J. Minimizing the damage: Repair pathways keep mitochondrial DNA intact. Nat. Rev. Mol. Cell Biol. 2012, 13, 659-671. [CrossRef]

72. Chakraborty, P.K.; Murphy, B.; Mustafi, S.B.; Dey, A.; Xiong, X.; Rao, G.; Naz, S.; Zhang, M.; Yang, D.; Dhanasekaran, D.N.; et al. Cystathionine beta-synthase regulates mitochondrial morphogenesis in ovarian cancer. FASEB J. 2018, 32, 4145-4157. [CrossRef] [PubMed]

73. Chandhok, G.; Lazarou, M.; Neumann, B. Structure, function, and regulation of mitofusin-2 in health and disease. Biol. Rev. Camb. Philos. Soc. 2018, 93, 933-949. [CrossRef] [PubMed]

74. Sykora, P.; Wilson, D.M., 3rd; Bohr, V.A. Repair of persistent strand breaks in the mitochondrial genome. Mech. Ageing Dev. 2012, 133, 169-175. [CrossRef] [PubMed]

75. Tann, A.W.; Boldogh, I.; Meiss, G.; Qian, W.; Van Houten, V.; Mitra, S.; Szczesny, B. Apoptosis induced by persistent singlestrand breaks in mitochondrial genome: Critical role of EXOG (5'-EXO/endonuclease) in their repair. J. Biol. Chem. 2011, 286, 31975-31983. [CrossRef]

76. Izumi, T.; Brown, D.B.; Naidu, C.V.; Bhakat, K.K.; MacInnes, M.A.; Saito, H.; Chen, D.J.; Mitra, S. Two essential but distinct functions of the mammalian abasic endonuclease. Proc. Natl. Acad. Sci. USA 2005, 102, 5739-5743. [CrossRef]

77. Abdel-Fatah, T.M.A.; Middleton, F.K.; Arora, A.; Agarwal, D.; Chen, T.; Moseley, P.M.; Perry, C.; Doherty, R.; Chan, S.; Green, A.R.; et al. Untangling the ATR-CHEK1 network for prognostication, prediction and therapeutic target validation in breast cancer. Mol. Oncol. 2015, 9, 569-585. [CrossRef]

78. Feng, W.; Dean, D.C.; Hornicek, F.J.; Wang, J.; Jia, Y.; Duan, Z.; Shi, H. ATR and p-ATR are emerging prognostic biomarkers and DNA damage response targets in ovarian cancer. Ther. Adv. Med. Oncol. 2020, 12, 1758835920982853. [CrossRef]

79. Li, C.-C.; Yang, J.-C.; Lu, M.-C.; Lee, C.-L.; Peng, C.-Y.; Hsu, W.-Y.; Dai, Y.-H.; Chang, F.-R.; Zhang, D.-Y.; Wu, W.-J. ATR-Chk1 signaling inhibition as a therapeutic strategy to enhance cisplatin chemosensitivity in urothelial bladder cancer. Oncotarget 2016, 7, 1947-1959. [CrossRef]

80. Jarrett, S.G.; Horrell, E.M.W.; Christian, P.A.; Vanover, J.C.; Boulanger, M.C.; Zou, Y.; D’Orazio, J.A. PKA-mediated phosphorylation of ATR promotes recruitment of XPA to UV-induced DNA damage. Mol. Cell 2014, 54, 999-1011. [CrossRef] 
81. Shilovsky, G.A.; Khokhlov, A.N.; Shram, S.I. The protein poly (ADP-ribosyl) ation system: Its role in genome stability and lifespan determination. Biochemistry 2013, 78, 433-444. [CrossRef] [PubMed]

82. Abdallah, Y.; Gligorievski, D.; Kasseckert, S.A.; Dieterich, L.; Schäfer, M.; Kuhlmann, C.R.; Noll, T.; Sauer, H.; Piper, H.M.; Schäfer, C. The role of poly (ADP-ribose) polymerase (PARP) in the autonomous proliferative response of endothelial cells to hypoxia. Cardiovasc. Res. 2007, 73, 568-574. [CrossRef]

83. Cohen-Armon, M.; Visochek, L.; Rozensal, D.; Kalal, A.; Geistrikh, I.; Klein, R.; Bendetz-Nezer, S.; Yao, Z.; Seger, R. DNAindependent PARP-1 activation by phosphorylated ERK2 increases Elk1 activity: A link to histone acetylation. Mol. Cell 2007, 25, 297-308. [CrossRef]

84. Kauppinen, T.M.; Chan, W.Y.; Suh, S.W.; Wiggins, A.K.; Huang, E.J.; Swanson, R.A. Direct phosphorylation and regulation of poly (ADP-ribose) polymerase-1 by extracellular signal-regulated kinases 1/2. Proc. Natl. Acad. Sci. USA 2006, 103, 7136-7141. [CrossRef] [PubMed]

85. Jiang, X.; MacArthur, M.R.; Treviño-Villarreal, J.H.; Kip, P.; Ozaki, C.K.; Mitchell, S.J.; Mitchell, J.R. Intracellular $\mathrm{H}_{2} \mathrm{~S}$ production is an autophagy-dependent adaptive response to DNA damage. Cell Chem. Biol. 2021, in press. [CrossRef] [PubMed]

86. Eliopoulos, A.G.; Havaki, S.; Gorgoulis, V.G. DNA damage response and autophagy: A meaningful partnership. Front. Genet. 2016, 7, 204. [CrossRef]

87. Gao, X.H.; Krokowski, D.; Guan, B.J.; Bederman, I.; Majumder, M.; Parisien, M.; Diatchenko, L.; Kabil, O.; Willard, B.; Banerjee, R.; et al. Quantitative $\mathrm{H}_{2} \mathrm{~S}$-mediated protein sulfhydration reveals metabolic reprogramming during the integrated stress response. eLife 2015, 4, e10067. [CrossRef]

88. Bautista-Niño, P.K.; Portilla-Fernandez, E.; Vaughan, D.E.; Danser, A.H.J.; Roks, A.J.M. DNA Damage: A main determinant of vascular aging. Int. J. Mol. Sci. 2016, 17, 748. [CrossRef]

89. Durik, M.; Kavousi, M.; van der Pluijm, I.; Isaacs, A.; Cheng, C.; Verdonk, K.; Loot, A.E.; Oeseburg, H.; Bhaggoe, U.M.; Roks, A.J.; et al. Nucleotide excision DNA repair is associated with age-related vascular dysfunction. Circulation 2012, 126, 468-478. [CrossRef] [PubMed]

90. Espach, Y.; Lochner, A.; Strijdom, H.; Huisamen, B. ATM protein kinase signaling, type 2 diabetes and cardiovascular disease. Cardiovasc. Drugs Ther. 2015, 29, 51-58. [CrossRef]

91. Halaby, M.J.; Hibma, J.C.; He, J.; Yang, D.Q. ATM protein kinase mediates full activation of Akt and regulates glucose transporter 4 translocation by insulin in muscle cells. Cell Signal. 2008, 20, 1555-1563. [CrossRef] [PubMed]

92. Cao, X.; Ding, L.; Xie, Z.A.; Yang, Y.; Whiteman, M.; Moore, P.K.; Bian, J.S. A Review of hydrogen sulfide synthesis, metabolism, and measurement: Is modulation of hydrogen sulfide a novel therapeutic for cancer? Antioxid. Redox Signal. 2019, 31, 1-18. [CrossRef]

93. Sundar, R.; Brown, J.; Russo, A.I.; Timothy, A.; Yap, T.A. Targeting ATR in cancer medicine. Curr. Probl. Cancer 2017, 41, 302-315. [CrossRef] [PubMed]

94. Yap, T.A.; Sandhu, S.K.; Carden, C.P.; De Bono, J.S. Poly (ADP-ribose) polymerase (PARP) inhibitors: Exploiting a synthetic lethal strategy in the clinic. CA Cancer J. Clin. 2011, 61, 31-49. [CrossRef]

95. Yazinski, S.A.; Comaills, V.; Buisson, R.; Genois, M.M.; Nguyen, H.D.; Ho, C.K.; Todorova Kwan, T.; Morris, R.; Lauffer, S.; Nussenzweig, A. ATR inhibition disrupts rewired homologous recombination and fork protection pathways in PARP inhibitorresistant BRCA-deficient cancer cells. Genes Dev. 2017, 31, 318-332. [CrossRef]

96. Blackford, A.N.; Jackson, S.P. ATM, ATR, and DNA-PK: The trinity at the heart of the DNA damage response. Mol. Cell 2017, 66, 801-817. [CrossRef]

97. Anand, S.K.; Sharma, A.; Singh, N.; Kakkar, P. Entrenching role of cell cycle checkpoints and autophagy for maintenance of genomic integrity. DNA Repair 2020, 86, 102748. [CrossRef] [PubMed]

98. Lee, J.H.; Paull, T.T. Mitochondria at the crossroads of ATM-mediated stress signaling and regulation of reactive oxygen species. Redox Biol. 2020, 32, 101511. [CrossRef]

99. Makinwa, Y.; Musich, P.; Zou, Y. Phosphorylation-dependent pin1 isomerization of ATR: Its role in regulating ATR's anti-apoptotic function at mitochondria, and the implications in cancer. Front. Cell Dev. Biol. 2020, 8, 281. [CrossRef]

100. Park, S.J.; Gavrilova, O.; Brown, A.L.; Soto, J.E.; Bremner, S.; Kim, J.; Xu, X.; Yang, S.; Um, J.H.; Koch, L.G.; et al. DNA-PK promotes the mitochondrial, metabolic, and physical decline that occurs during aging. Cell Metab. 2017, 25, 1135-1146. [CrossRef] 